Przegląd Badań Edukacyjnych Educational Studies Review

ISSN 1895-4308

nr $19(2 / 2014)$, s. 43-60

ORYGINALNE

ARTYKUtY

BADAWCZE

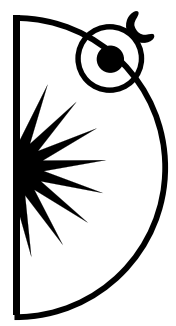

Adrianna Sarnat-Ciastko

Akademia im. Jana Długosza w Częstochowie, e-mail: adrianna.ciastko@gmail.com

\title{
Czy mnie dostrzegasz, czy odpowiadasz na moje potrzeby? Obecność znaków rozpoznania w relacji tutorów szkolnych i ich podopiecznych. Perspektywa uczniów
}

DOI: http://dx.doi.org/10.12775/PBE.2014.021

\section{Can You See Me? Do You Respond to My Needs? The Presence of Strokes in the Relationship of Teachers and Students. The Pupils' Perspective}

\begin{abstract}
School can be describe in numerous ways. One of them are the well-known PISA surveys prepared by The Organization for Economic Co-operation and Development (OECD) which focus on reading, text interpreting, mathematical and scientific skills of 15 -year-old teens. This kind of research activity is not surprising in the post-industrial world. Measuring pupils' knowledge is valuable because knowledge is the key to their better lives, better jobs, better opportunities. However, from pedagogical perspective there is the other side of this coin - the human nature. The atmosphere at school, good relations, personal development, creativity, the sense of security etc., can change both pupils' and teachers' lives. The author of this paper shows that personal teaching (tutoring) can be an interesting option for public schools in Poland. She proves that the quality of this kind of contact gives schools better educational tools. What is important - the basis which allowed to draw such conclusions is research based on the concept of transactional analysis, especially the stroke theory.
\end{abstract}

Keywords: Educational transactional analysis; stroke theory; relationship between teacher and pupil 
Pod koniec 2013 r. Organizacja Współpracy Gospodarczej i Rozwoju (OECD) opublikowała kolejny już raport poświęcony Międzynarodowej Ocenie Umiejętności Uczniów (Programme for International Student Assessment-PISA) ${ }^{1}$. W prezentowanych badaniach wzięło udział przeszło pół miliona 15-latków z 65 krajów bądź stref ekonomicznych. Badania po raz kolejny objęły również młodzież z Polski, która tym razem wypadła w nich nad wyraz dobrze, zajmując średnio 13 pozycję w rankingu ex quo z ich rówieśnikami z Kanady (http:// www.oecd.org). Zaraz po ogłoszeniu wyników badań prasa uznała, że polscy uczniowie są w światowej czołówce (Suchecka, 2013) i jest to sukces rodzimej edukacji. Oczywiście można przyznać, że osiagnięcie lepszych wyników niż w ostatnim badaniu PISA musi budzić satysfakcję, czy jednak o faktycznym poziomie polskiej szkoły decydować ma skuteczność wypełniania przez uczniów testów (Czubkowska, 2013), których wyników, z uwagi na różnice kultur i systemów kształcenia w badanych krajach, nie da się do końca porównać (http:// montrose42.wordpress.com)?

Pytanie o to, czy o jakości polskiego systemu oświaty ma decydować przede wszystkim poziom zdawalności testów, pozostaje nad wyraz aktualne. Gdyby spojrzeć bowiem na rozkład procentowy opinii badanych uczniów, dotyczącej odczuwanego przez nich poziomu szczęścia z powodu pobytu w szkole, okazuje się, że polska młodzież znalazła się w tej kategorii na 58 miejscu (http://www.oecd.org). Bezsprzecznie atmosfera i relacje między członkami szkolnej społeczności odgrywają tutaj kluczową rolę. Autorka niniejszego artykułu zdecydowała się ukazać w nim ten właśnie aspekt, przyjmując przy tym „uczniowską” perspektywę. Będzie to jednak specyficzna perspektywa, która pozwoli na podjęcie próby szukania odpowiedzi na pytanie: jak uczniowie oceniają poziom dostrzegania ich przez nauczycieli. W tym kontekście zatem nie będą brane pod uwagę umiejętności młodzieży, ale doświadczana przez nich obecność i wsparcie ze strony ich dorosłych opiekunów.

Należy zaznaczyć, iż w poszukiwaniu odpowiedzi na powyższe pytanie autorka posłużyła się koncepcją analizy transakcyjnej. Ten wybór nie był jednak przypadkowy. Odwoływanie się do tego podejścia z jednej strony stanowiło

${ }^{1}$ Narzędzie to pozwala określać jakość oraz tendencje światowego szkolnictwa, poprzez ocenę poziomu posługiwania się wiedzą przez młodzież, która ukończyła 15 rok życia. PISA sprawdza zatem zdolność nastolatków do „rozwiązywania problemów, analizowania, argumentowania i interpretowania. Bada umiejętność myślenia i przygotowanie do dorosłego życia" [J. Suchecka, 2013]. Koncentruje się jednak tutaj na trzech podstawowych dziedzinach: czytaniu i interpretacji tekstu, matematyce oraz rozumowaniu w naukach przyrodniczych. 
dla niej naturalną konsekwencję podejmowanych na co dzień rozważań ${ }^{2}$ z drugiej zaś zapewniało narzędzia pozwalające w sposób precyzyjny opisać zastaną w badanych szkołach rzeczywistość.

\section{Zastosowanie analizy transakcyjnej w badaniu szkolnych relacji}

Twórca analizy transakcyjnej (AT) Eric Berne w jednej ze swoich monografii stwierdził, że stworzona przez niego koncepcja bazuje na specyficznej teorii osobowości (Berne, 1978, s. X). Teorii, która mówi, iż ludzie są w swojej istocie $\mathrm{OK}^{3}$, czyli mają swoją wewnętrzną wartość i prawo do istnienia; potrafią myśleć poprzez gromadzenie informacji i podejmowanie decyzji, a także potrafią się zmieniać (Barrow, 2007, s. 21). Zatem, jak twierdzi Giles Barrow, mają zdolność do rozwoju i nauki, co ma niebagatelne znaczenie dla zastosowania tej koncepcji na gruncie edukacji. Choć na początku fakt ten wydawał się kwestią drugorzędna, gdyż analityków transakcyjnych przede wszystkim interesowała działalność psychoterapeutyczna, jednak wraz z upływem czasu odwołania AT do edukacji stawały się coraz częstsze. Sam E. Berne już w 1966 r. w monografii poświęconej zasadom terapii grupowej w rozdziale pod znamiennym tytułem Nauczanie zaznaczył, jaką wartością jest dobre przygotowanie osoby do pełnienia funkcji analityka transakcyjnego - opisując ze szczegółami system, w jakim ten winien zdobywać wiedzę i umiejętności (Berne, 1978, s. 159-184).

Oczywiście edukacja w AT ma również inne wymiary. Prócz organizacji systemu nauczania przyszłych analityków transakcyjnych, a także przekazywania wiedzy o tej koncepcji tym, którzy wykazują takie zainteresowanie, analiza transakcyjna stanowi użyteczne narzędzie do opisywania rzeczywistości, w tym rzeczywistości szkolnej. W sposób niepozostawiający żadnych wątpliwości stanowisko w tej sprawie zajmuje Dorota Pankowska, która zauważa, że AT ma tutaj na celu ,przede wszystkim wspomaganie rozwoju, co oznacza:

- tworzenie nowych perspektyw efektywnego procesu nauczania-uczenia się,

${ }^{2}$ Autorka niniejszego artykułu jest członkiem Zespołu Badawczego Edukacyjnej Analizy Transakcyjnej, który działa na Wydziale Pedagogicznym Akademii im. J. Długosza w Częstochowie od marca $2010 \mathrm{r}$.

3 Określenie „OK”, które w języku polskim jest stosowanym potocznie zapożyczeniem, w terminologii AT znajduje swoje miejsce w koncepcji transakcyjnych pozycji życiowych, będących fundamentalnym punktem widzenia przyjmowanym przez człowieka względem siebie i własnego otoczenia (por. Jagieła, 2012, s. 153). 
- możliwość analizowania i interpretowania w nowy sposób różnych koncepcji edukacyjnych,

- dostarczenie metod interwencji w przypadku trudności dydaktyczno-wychowawczych,

- zwiększenie szansy dla wzrostu samoświadomości i osobistego rozwoju, tak dla uczących się, jak dla edukatorów" (Pankowska, 2012, s. 15).

U podstaw opisywania różnorodnych wymiarów edukacji (w tym również relacji uczeń-nauczyciel) za pomocą siatki pojęć analizy transakcyjnej leży bez wątpienia potrzeba pogłębionego wglądu w samą koncepcję E. Berne'a. Jego podejście opiera się na analizie czterech podstawowych przestrzeni funkcjonowania człowieka, umiejscowionych w nim samym i jego relacji do otoczenia. W pierwszej kolejności AT pozwala na analizę osobowości jednostki poprzez opis jego stanów Ja (stanów ego) określanych mianem spójnych systemów myśli, uczuć oraz doświadczeń, które manifestują się swoistymi zachowaniami (Berne, 2007, s. 507). Ponadto analiza transakcyjna, znajdując się w obszarze koncepcji zorientowanych humanistycznie, stara się umiejscowić człowieka, rodzącego się z ,ogromnym potencjałem w rozumieniu, odczuwaniu, myśleniu i zachowaniu" (Gregory, 2000, s. 152) w określonym czasie i przestrzeni. Ta sytuacja dotyczy podejmowanych przez niego we wczesnym dzieciństwie decyzji oraz roli, jaką w jego życiu wywarli rodzice czy też znaczący dorośli (teoria skryptu), ale także stosunku danej osoby do innych ludzi (pozycje życiowe, strukturalizacja czasu). Dodatkowo w centrum zainteresowania AT pozostaje komunikacja międzyludzka, którą można opisać poprzez transakcje - będące podstawowymi jednostkami działań społecznych (tamże), ale także znaki rozpoznania zwane stroukami ${ }^{4}$.

\section{Znaki rozpoznania}

Lulula de Quintero i Doris Boersner, definiując znaki rozpoznania, dostrzegły, iż w analizie transakcyjnej termin ten ma duże znaczenie, a nawet „mówi się,

${ }^{4}$ Należy zaznaczyć, iż w niniejszym artykule zamiennie z nazwą „,znak rozpoznania” będzie stosowany termin „strouk”. Określenie to wywodzi się ze stosowanego w terminologii AT angielskiego pojęcia „stroke”, które oznacza: wsparcie, wzmocnienie, uznanie bądź głask. Używanie terminów „znak rozpoznania” bądź „strouk” pozwala na opis tego zjawiska bez określania jego pozytywnych i negatywnych aspektów, które w sposób precyzyjny będą w odpowiednich momentach prezentowane. Samo pojęcie „strouk” w języku polskim, wśród osób interesujących się bądź korzystających z analizy transakcyjnej, przyjęło się jako swoisty neologizm, gdyż pozwoliło na zachowanie ciagłości znaczenia tego terminu, bez konieczności jego tłumaczenia. Co ciekawe jednak, wymowa angielskiego słowa „stroke” została spolszczona na: „strok”, „strouk”, a nawet „streuk”. 
że strouki są najsilniejszym narzędziem analizy transakcyjnej” (de Quintero, Boersner, 1982, s. 309). Ich siła wynika z tego, że są one głęboko pożądane przez jednostki, które potrzebują znaków rozpoznania tak jak pożywienia czy psychicznej stymulacji (por. Dieser, 1997, s. 175). Strouki określane są zatem jako rodzaj „medium, poprzez które komunikujemy się z innymi, wyrażając im uznanie za to kim są bądź co robią" (de Quintero, Boersner, 1982, s. 309). W ten sposób znaki rozpoznania mogą odnosić się do wszystkich sfer funkcjonowania jednostki - fizycznej, emocjonalnej i społecznej (por. Oller-Vallejo, 1994, s. 185). Bez wątpienia przez ich obecność określa się wartość osoby, która obdarzana takim rodzajem wsparcia może czuć się dostrzeżona i zaakceptowana. Tym samym ma możliwość budowania pozytywnego obrazu siebie i otoczenia, które poprzez udzielanie pozytywnych znaków rozpoznania może wydawać się przyjazne i otwarte. Bądź odwrotnie, poprzez przekazywanie negatywnych strouków - staje się wrogie, niedające odpowiednich warunków do rozwoju.

Analitycy transakcyjni, przyglądając się znakom rozpoznania zauważyli, iż te mogą znacząco różnić się od siebie. W literaturze przedmiotu można znaleźć kilka kategorii ich podziału. Mogą być one zatem:

- warunkowe lub bezwarunkowe - odnoszące się do bezwzględnej wartości osoby jako takiej (bezwarunkowy znak rozpoznania np. stwierdzenie „»Kocham cię«, które zawiera wiadomość »Całkowicie akceptuję twoje jestestwo«" (Oller-Vallejo, 1994, s. 185)), bądź osoby wartościowanej przez pryzmat realizowanych przez nią działań (warunkowy znak rozpoznania np. „Będziesz kochany, gdy posprzątasz pokój”);

- pozytywne (zwane „puszkami”s) bądź negatywne (określane mianem „kolczatek”) - określane przez swoich odbiorców odpowiednio jako przyjemne, budujące, akceptujące bądź nieprzyjemne, niszczące;

- werbalne bądź niewerbalne - wyrażane słownie (werbalnie) bądź przy użyciu gestów, postawy ciała, tonu głosu (niewerbalnie);

- fałszywe (plastikowe) bądź prawdziwe - świadczące o intencjach nadawcy, które w przypadku fałszywych strouków moga jedynie pozornie przypominać np. pozytywny znak rozpoznania;

- wewnętrzne bądź zewnętrzne - wskazujące na nadawcę, którym może być sam adresat znaków rozpoznania (obdarzający siebie autogłaskiem) lub też osoba $\mathrm{z}$ otoczenia adresata.

${ }^{5}$ Należy zauważyć, iż przyjęto, aby w terminologii analizy transakcyjnej stosować pojęcia potoczne, obrazowe, zatem takie, jakie będą użyteczne w relacji z klientem. Stąd też m.in. typowe dla AT określenia „puszki” bądź „kolczatki”. 
Biorąc pod uwagę powyższe zestawienie, warto zaznaczyć, iż ten podział, pozwalający zilustrować charakter strouków, w rzeczywistości jest płynny. Częstokroć w życiu codziennym, choćby w szkole, uczniowie są obdarzani przez nauczycieli znakami rozpoznania, które jednocześnie mogą być np. warunkowe-werbalne-pozytywne co mieścić się może w zdaniu: „Wspaniała ocena! Wiedziałem, że mogę na ciebie liczyć", lub warunkowe-niewerbalne-negatywne obecne w chwili, gdy nauczyciel pokazuje swojemu podopiecznemu ocenę ze sprawdzianu, obdarzając go karcącym spojrzeniem i kiwaniem głową z dezaprobatą.

Koncepcja znaków rozpoznania oczywiście pozwala na precyzyjną analizę sposobów ich udzielania bądź otrzymywania, jednakże praktyka AT zwraca uwagę na aspekty, które powinny być w centrum zainteresowania badaczy tego zjawiska. Zdaniem analityków transakcyjnych największe znaczenie mają tutaj strouki pozytywne, które dawane przez osoby znaczące, najsilniej oddziałują na samoocenę jednostki, na dostrzeżenie przez nią własnych unikalnych cech i akceptację swojego istnienia (por. Oller-Vallejo, 1994, s. 186), zaspokajając przy tym trzy istotne potrzeby: uznania, poczucia własnej wartości oraz bezpieczeństwa (por. Rogoll, 2010, s. 44). Jak jednak zauważył Rüdiger Rogoll, otrzymywanie znaków rozpoznania, nawet jeśli są one negatywne, jest zawsze lepsze dla jednostki aniżeli doświadczany przez nią zupełny brak strouków (por. tamże, s. 48). Stąd też przyjmuje się, że dla osób pozbawionych pozytywnych znaków rozpoznania obecność znaków negatywnych, np. będących reakcją otoczenia na ich aspołeczne zachowanie, oznacza mimo wszystko możliwość bycia zauważonym. Dlatego też w tej właśnie potrzebie analiza transakcyjna widzi potencjał do możliwej zmiany. Co ważne, tego typu „Interakcja między ludźmi, rozumiana jako okazja do wymiany znaków rozpoznania/głasków, pozwala wyjaśnić wiele zachowań w relacjach interpersonalnych oraz działań podejmowanych przez jednostki [...]" (Pankowska, 2010, s. 62). Owa możliwość wyjaśnienia zachowań, w których obecne są wymienione ,akty zwracania uwagi na obecność innej osoby” (Berne, 2004, s. 9), stała się podstawą do zilustrowania specyficznych relacji szkolnych między tutorem a podopiecznym.

\section{Tutoring w rzeczywistości polskiej szkoły}

Opisywanie tutoringu w odniesieniu do działalności szkół nie wydaje się zjawiskiem nowym. Tutor kojarzony jest bowiem już od dawna przede wszystkim z funkcjonowaniem anglosaskich placówek oświatowych, gdzie do jego zadań należy sprawowanie opieki „nad tokiem studiów oraz codziennym zachowa- 
niem swoich podopiecznych w szkole i poza nią" (Okoń, 1981, s. 324). Samo pojęcie „tutor” jest jednak znacznie szersze i określa w języku angielskim: opiekuna, wychowawcę, guwernera, korepetytora, asystenta nauczyciela bądź nauczyciela akademickiego, który kieruje indywidualnie pracą przydzielonej mu grupy studentów (por. Linde-Usiekniewicz, 2005, s. 836). Ów ostatni aspekt jest szczególnie istotny dla scharakteryzowania tej funkcji, gdyż kluczowa pozostaje tutaj indywidualna relacja tutora $\mathrm{z}$ podopiecznym. $\mathrm{Z}$ tym też wiąże się geneza zjawiska tutoringu, którego źródłem według literatury miał stać się rozwój kształcenia na uniwersytecie w Oksfordzie już w XIV-XV w. (Fijałkowski, 2009, s. 11). Zadaniem ówczesnych tutorów miało być ni mniej ni więcej, ale realizowanie indywidualnych zajęć ze studentami, którzy przypisani byli do danego kolegium (tamże). Mimo upływu wieków metoda ta w dalszym ciagu obecna jest w brytyjskim szkolnictwie wyższym, stanowiąc swoisty powód do dumy (Curzon, za: Tapper, Palfreyman, 2000, s. 101). Być może o takim stanie rzeczy zdecydował fakt, że przez możliwy kontakt z tutorem w szczególny sposób rozwijana była zdolność analitycznego myślenia oraz umiejętnego budowania wypowiedzi, czego podstawą były toczące się w ramach spotkań studenta i tutora dyskusje (por. Hejwosz, 2010, s. 198-199). Co istotne jednak, działalność tutorów nie ograniczyła się jedynie do przestrzeni akademickiej, a zaistniała $\mathrm{z}$ powodzeniem w obszarze edukacji dorosłych, w ramach promowanych na początku XX w. przez Robotnicze Stowarzyszanie Oświatowe klas tutorialnych, przeznaczonych dla chcących dokształcić się angielskich robotników (por. Sarnat-Ciastko, 2011, s. 102). Tutoring (peer-tutoring, cross-age tutoring) znalazł również swoje miejsce w dziedzinie szeroko pojętej edukacji rówieśniczej (Wagner, 1982) bądź edukacji realizowanej przez nieprofesjonalnych nauczycieli (por. Topping, 1994, s. 23).

Należy zauważyć, że w odniesieniu do doświadczeń anglosaskich działalność tutorów w przestrzeni polskiej edukacji była ograniczona. Oczywiście znane są postaci nauczycieli indywidualnych (prywatnych), którzy - począwszy od Jana Długosza czy Grzegorza Piramowicza, mieli niebagatelny wpływ nie tylko na swoich wychowanków (por. Fijałkowski, 2009, s. 15-22). Znacząca pozostaje również rola Uniwersytetu Latającego, czerpiącego wzorce $\mathrm{z}$ angielskiego Uniwersytetu Otwartego, gdzie również obecni byli tutorzy (por. Półturzycki, 1999, s. 312). W tym kontekście trudno jednak szukać przykładów, w których to tutoring, stanowiący swoistą metodę kształcenia indywidualnego, był stosowany powszechnie w publicznych instytucjach oświatowych. Ta sytuacja uległa jednak znacznym zmianom, kiedy to od $2008 \mathrm{r}$. metoda ta stopniowo zaczęła pojawiać się w szczególności w dolnośląskich liceach oraz gimnazjach, 
gdzie obecnie w samym tylko Wrocławiu znaleźć można 3490 uczniów objętych tutoringiem oraz 349 nauczycieli występujących w roli tutorów (Sprawozdanie Prezydenta Miasta Wroctawia z realizacji zadań w 2012 r., 2013, s. 207-208).

Odnosząc się do obecnej „ekspansji” tutoringu, ta wiąże się ściśle z działalnością liderów - edukatorów, którzy uznali, iż edukacja indywidualna może stanowić istotny bodziec do zmiany relacji panujących w polskiej szkole. Prym w tym działaniu wiedzie Kolegium Tutorów - instytucja powołana przez członków Towarzystwa Edukacji Otwartej z Wrocławia w 2006 r. (http://www.tutoring.pl). Warto jednak dostrzec, że dla inicjatorów procesu wdrażania opisywanej metody, ta realizowana jest pod hasłem tutoringu szkolnego, który zakłada bezpośredni i indywidualny kontakt nauczyciela z uczniem, ze szczególnym uwzględnieniem ich godności „wypływającej z faktu ich człowieczeństwa; inter- $\mathrm{i}$ intraakcyjności procesu wychowawczego oraz jego osadzenia w konkretnej rzeczywistości szkolnej” (Budzyński, 2009, s. 31). Co ważne, w metodzie tutoringu szkolnego opartej na koncepcji pedagogiki dialogu przyjmuje się, że relacja tutorska to długofalowy proces wzajemnej współpracy ucznia i nauczyciela, który nakierowany jest na jego integralny rozwój.

Jak dotąd praktyka tutorów szkolnych ${ }^{6}$ pokazuje, iż opisywana metoda obecna jest $w$ trzech płaszczyznach: rozwojowej, naukowej i artystycznej (tamże, s. 31-34). W kontekście niniejszego artykułu istotna jest charakterystyka pierwszej z nich. Tutoring rozwojowy stanowi wyraźną alternatywę dla realizowanego w polskich szkołach wychowawstwa klasowego. Zgodnie $\mathrm{z}$ jego założeniami funkcje wychowawcze względem danego ucznia w szkole pełni wybrany przez ucznia nauczyciel-tutor, który z jednej strony ma wypełniać formalne zadania dotychczasowego opiekuna, z drugiej zaś umiejętnie budować z uczniem indywidualną relację?. Co ważne, wybór dotyczy

${ }^{6}$ Mówiąc o tutorach szkolnych, nie można zapomnieć, iż wdrażana do szkół publicznych metoda tutoringu z jednej strony czerpie inspiracje z doświadczeń anglosaskich szkół wyższych, z drugiej zaś z praktyki nauczycieli-opiekunów pracujących w Autorskich Liceach Artystycznych i Akademickich „ALA”, mieszczących się we Wrocławiu i Częstochowie. Placówki powołane do życia odpowiednio w 1995 i 2003 r. od samego początku zrezygnowały z funkcji wychowawcy klasowego, dając swoim uczniom możliwość wyboru indywidualnego opiekuna, który miał im pomóc m.in. w ustaleniu planu rozwoju. Z czasem opiekunowie z „ALA” dostali możliwość przejścia szkolenia, które dawało im umiejętności pracy metodami tutorskimi. Tym samym większość opiekunów stała się w tych szkołach tutorami.

${ }^{7}$ Należy zaznaczyć, iż przedstawiane tutaj założenia tutoringu rozwojowego są elastycznie dopasowywane do możliwości szkół publicznych. Placówki przyjmują tę koncepcję w całości bądź w pewnych ograniczeniach. Zmianom najczęściej podlega rola wychowawcy, który w nie- 
jedynie tych nauczycieli, którzy wyrażą zainteresowanie taką formą działalności, przejdą odpowiednie szkolenie, a następnie zgodzą się na propozycję ucznia. Celem nawiązanej w ten sposób relacji ma być poznanie podopiecznego, odkrywanie jego talentów, ale także określanie i realizacja planów rozwojowych.

Tutoring odbywa się w atmosferze zaufania i poczucia bezpieczeństwa. Same spotkania mają się odbywać stosunkowo często - co tydzień dochodzi do krótszych podtrzymujących więź kontaktów, natomiast raz w miesiącu tutorial ma trwać minimum 40 minut. Tutor zatem ma być nauczycielem zaangażowanym, a jego uwagę może skupiać grupa maksymalnie 10 podopiecznych. Takie założenia tutoringu sprawiają, że uczeń ma szansę na bezpośredni, autentyczny kontakt z wybraną osobą dorosłą. Czy jednak taka sytuacja faktycznie ma miejsce? Czy tutoring w odróżnieniu od klasycznego wychowawstwa klasowego w większym stopniu sprzyja budowaniu relacji między uczniem a nauczycielem? Wydaje się, że kwestia ta możliwa jest do zweryfikowania m.in. poprzez wgląd w poziom obecnych w obu relacjach znaków rozpoznania.

\section{Odbiór strouków dawanych uczniom przez nauczycieli - badania własne}

Dorota Pankowska dostrzegła, że: „Właściwe dawanie znaków rozpoznania uczniom przez nauczycieli nie tylko wzmacnia ich poczucie wartości, ale wpływa na proces i efekty kształcenia" (Pankowska, 2010, s. 178). Biorąc to pod uwagę, można przyjąć, iż wgląd w ten aspekt szkolnej praktyki pozwala wykazać intensywność i jakość wzajemnego kontaktu ucznia z nauczycielem. $\mathrm{W}$ odniesieniu zatem do tego zdecydowano się na przeprowadzenie procedury badawczej, której celem stało się wskazanie poziomu udzielania znaków rozpoznania uczniom zarówno przez wychowawców klasowych, jak i przez tutorów. Podjęte działania miały służyć określeniu, czy z perspektywy uczniów istnieją różnice w poziomie i charakterze strouków udzielanych im przez nauczycieli w relacji tutorskiej bądź wychowawczej. Do tak postawionego problemu badawczego odniesiono hipotezę (opartą na zawartej w literaturze przedmiotu

których oddziałach zostaje i pełni swoje dotychczasowe zadania, gdy w innych - formalnymi aspektami pracy wychowawcy dzieli się między sobą zespół klasowych tutorów. Odrębną kwestią pozostaje wolność wyboru opiekuna przez ucznia, która w zależności od placówki może być większa lub mniejsza, bądź może jej nie być w ogóle. Mimo tych ograniczeń niezmienna pozostaje możliwość korzystania z indywidualnej pomocy tutora. 
charakterystyce pracy tutorskiej), w której uznano, iż to relacja tutorska w większym stopniu niż relacja wychowawcy klasowego z podopiecznymi wypełniona będzie stroukami, mającymi w znacznej mierze charakter pozytywny.

Należy zaznaczyć, że oparta na powyższych założeniach procedura badawcza ${ }^{8}$ zrealizowana została przy użyciu metody sondażu diagnostycznego. Wzięło w niej udział 391 uczniów z 33 szkół gimnazjalnych i średnich z terenu Częstochowy (20 szkół) i Wrocławia (13 szkół). Wśród nich znalazło się:

- 153 podopiecznych wychowawców szkolnych, którzy nie stosowali metody tutoringu;

- 108 uczniów Autorskich Liceów Artystycznych i Akademickich „ALA”, którzy w tych szkołach nie doświadczyli pracy innej niż z indywidualnym opiekunem (tutorem);

- 130 podopiecznych tutorów ze szkół publicznych wdrażających tutoring szkolny, w których obecni są w dalszym ciagu również wychowawcy.

Taki dobór badanych umożliwić miał porównanie ze sobą ich opinii, w pozyskaniu których służył kwestionariusz „Relacja podopieczny-tutor” lub „Relacja uczeń-wychowawca". Narzędzie to przeznaczone było dla wszystkich z grupy i różniło się jedynie zwrotami typu „twój tutor” bądź „twój wychowawca". Należy zaznaczyć, że inspiracją do stworzenia tego kwestionariusza okazała się budowa „Profilu znaków rozpoznania” Jima McKenny (1974) oraz mechanizm tworzenia dyferencjału semantycznego. „Profil znaków rozpoznania”, choć w tym przypadku nie został uznany za wystarczające narzędzie badawcze, wskazał jednak, iż w tworzonym kwestionariuszu zasadne jest ujęcie terminów takich jak: „dawanie”, „branie”, „proszenie” czy „odmawianie dawania" (por. Pankowska, 2010, s. 176). Z kolei wykreowany przez Charlesa E. Osgooda, George'a J. Suci'ego i Percy'ego H. Tannenbauma (por. Czapiński, 1978, s. 257) dyferencjał służący do badania postaw i opinii, stał się tutaj swoistą kanwą, na której zamiast przymiotników zostały ułożone w opozycji do siebie zdania odnoszące się w równej liczbie do otrzymywanych przez ucznia od nauczyciela pozytywnych i negatywnych strouków. W ten sposób badany uczeń

${ }^{8}$ Warto podkreślić, iż opisane w niniejszym artykule badania stanowiły część większej procedury trwającej od kwietnia do października 2012 r., której celem było określenie rozwoju tutoringu szkolnego w polskim systemie oświaty oraz efektów oddziaływania tej metody na nauczyciela i ucznia i ich wzajemną relację w świetle analizy transakcyjnej. Całość w sposób ścisły wiązała się z przygotowywaną przez autorkę tekstu rozprawą doktorską. 
miał na 5-stopniowej skali, rozpiętej między opozycyjnymi względem siebie stwierdzeniami, ocenić poziom poszczególnych (przykładowych) znaków rozpoznania dawanych mu przez nauczyciela. Zatem tutaj tutor/wychowawca obdarowywał ucznia pozytywnym wsparciem, gdy: prosił go o pomoc, dzielił się z nim uwagami, dawał wyrazy akceptacji, chwalił i słuchał. Z kolei kolczatka skierowana od opiekuna do podopiecznego pojawiała się, gdy ten: lekceważył go, dawał mu nauczki, krytykował, odmawiał mu pomocy oraz stroił sobie z niego żarty9. Trafność doboru powyższych stwierdzeń została potwierdzona przez sędziów kompetentnych - osób znających dobrze koncepcję analizy transakcyjnej. Przed badaniami zasadniczymi kwestionariusz został wykorzystany w badaniach pilotażowych. W ostateczności uzyskane za jego pomocą dane posłużyły do dokonania analizy rzetelności (obliczenie współczynnika $\alpha$-Cronbacha), która potwierdziła, iż narzędzie to może być wykorzystywane w dalszej procedurze.

Podczas realizacji badań właściwych można było zaobserwować, że wypełnianie kwestionariusza nie stanowi dla uczniów problemu. Ci chętnie wskazywali swoją ocenę $\mathrm{w}$ odniesieniu do prezentowanych stwierdzeń, które były dla nich czytelne i wystarczająco obrazowe. Co istotne - pozyskane dane pokazały nieznaczne różnice w postrzeganiu tutorów zarówno przez uczniów Autorskich Liceów Artystycznych i Akademickich „ALA”, jak i szkół wdrażających tę metodę. Ta sytuacja pozwoliła zatem odnosić się łącznie do tych dwóch grup badanych. W tym kontekście istotne statystycznie różnice (test U Manna Whitneya dla poziomu istotności $\mathrm{p}<0,05$ ) względem opinii podopiecznych tutorów, można było dostrzec w opiniach uczniów, którzy mają wychowawców klasowych. Uzyskane wyniki prezentuje rysunek 1.

Rysunek 1 zestawia średnie oceny uzyskane po przekształceniu pomiaru ze skali porządkowej na interwałową (por. Rubacha, 2008, s. 93). Warto dostrzec, iż wartości rozpięte są tutaj między opozycyjnymi stwierdzeniami - i im znajdują się bliżej brzegów, tym badani bardziej utożsamiali się z określonym itemem. „Środkowe” wskazania odpowiadają za postawę ambiwalentną uczniów, która szczególnie uwidacznia się w jednym przypadku. Dotyczy on określenia

${ }^{9} \mathrm{~W}$ tym miejscu warto wyjaśnić, że w opisywanym narzędziu znalazło się po 5 stwierdzeń (itemów) przypisanych negatywnym i pozytywnym znakom rozpoznania. Jest to niewielka, aczkolwiek wystarczająca liczba, która pozwalała na określenie swoistej tendencji Co ważne, uzasadnieniem, dla którego kwestionariusz ten nie był bardziej rozbudowany, była koniczność wypełnienia przez grupę badanych dodatkowo trzech innych narzędzi badawczych podczas jednego spotkania. 
przez licealistów i gimnazjalistów korzystających z tutoringu, na ile tutorzy skłonni są prosić ich o udzielenie pomocy. W tym przypadku warto jednak uzupełnić powyższy obraz o dane znajdujące się w tabeli 1 , gdzie dostrzec można różnicę w zdaniach podopiecznych „ALA” i szkół wdrażających ${ }^{10}$. W opinii tych pierwszych - tutorzy w mniejszym stopniu proszą ich o pomoc. Można założyć, że ta sytuacja ma jednak swoje uzasadnienie w autorskiej koncepcji szkół „ALA”, która w dużej mierze opiera się na wolności i samodzielności zarówno licealistów, jak i nauczycieli.

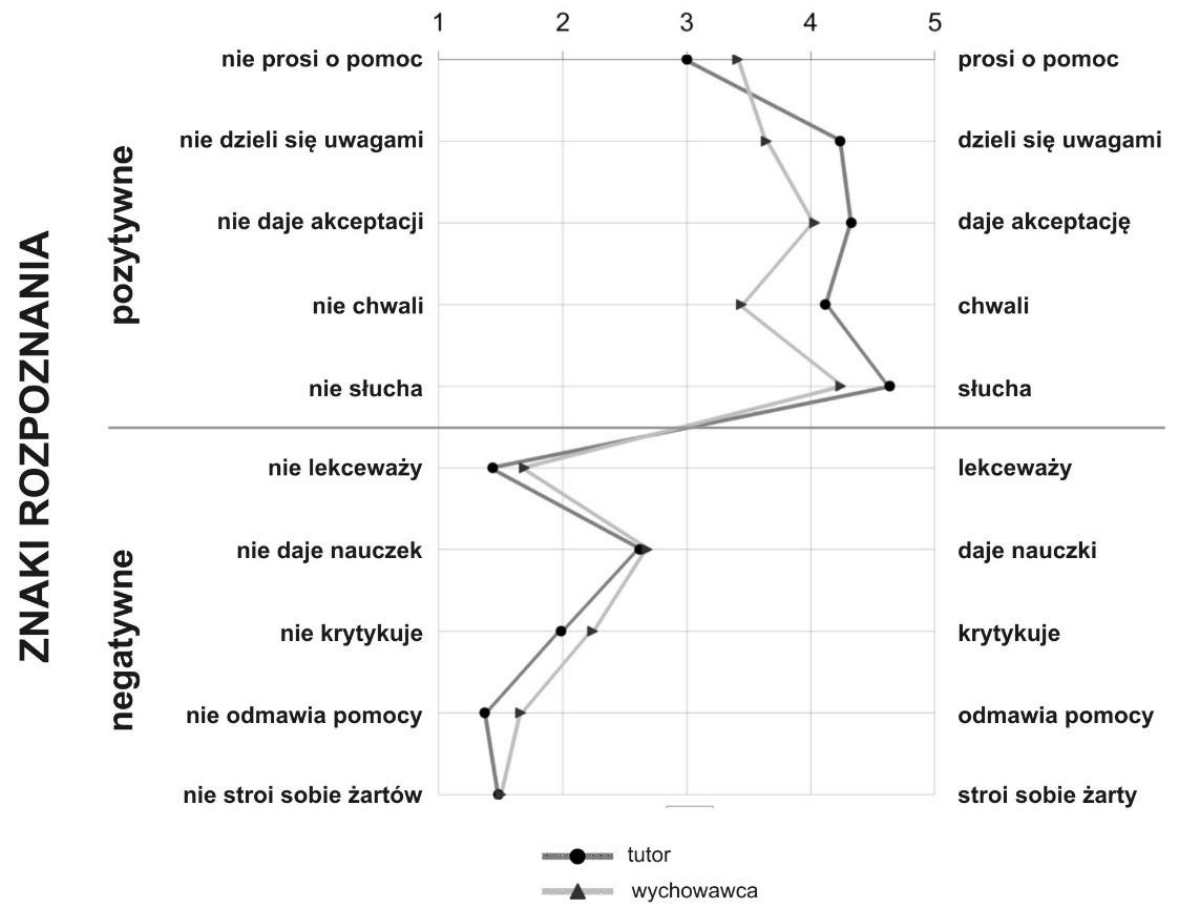

Rysunek 1. Poziom udzielanych uczniom przez nauczycieli znaków rozpoznania, z wyróżnieniem grupy opiniowanych przez podopiecznych tutorów i wychowawców

Źródło: opracowanie własne.

${ }^{10}$ Rysunek 1 prezentuje uśrednione wartości pomiaru uzyskanych przez uczniów „ALA” i szkół wdrażających tutoring, co pozwoliło na stworzenie bardziej czytelnej graficznej prezentacji. 
Tabela 1. Średnie wartości poziomu udzielanych uczniom przez nauczycieli znaków rozpoznania $(\mathrm{N}=391)$

\begin{tabular}{|c|c|c|c|c|c|}
\hline \multirow{2}{*}{\multicolumn{3}{|c|}{$\begin{array}{l}\text { Znaki rozpoznania dawane uczniom } \\
\text { przez tutorów/wychowawców }\end{array}$}} & \multicolumn{3}{|c|}{ Średnie wartości pomiaru opinii uczniów } \\
\hline & & & \multirow{2}{*}{$\begin{array}{c}\text { ze szkół „ALA" } \\
2,88\end{array}$} & \multirow{2}{*}{$\begin{array}{c}\begin{array}{c}\text { ze szkół wdraża- } \\
\text { jących tutoring }\end{array} \\
3,12 \\
\end{array}$} & \multirow{2}{*}{$\begin{array}{c}\begin{array}{c}\text { ze szkół z tradycyjnym } \\
\text { wychowawstwem }\end{array} \\
3,41 \\
\end{array}$} \\
\hline \multirow{10}{*}{ 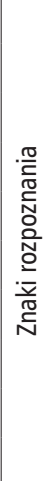 } & \multirow{5}{*}{ 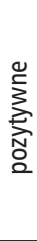 } & prosi o pomoc & & & \\
\hline & & dzieli się uwagami & 4,32 & 4,15 & 3,64 \\
\hline & & daje wyrazy akceptacji & 4,39 & 4,26 & 4,03 \\
\hline & & chwali & 4,13 & 4,1 & 3,44 \\
\hline & & słucha & 4,6 & 4,67 & 4,24 \\
\hline & \multirow{5}{*}{ 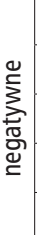 } & lekceważy & 1,54 & 1,33 & 1,69 \\
\hline & & daje nauczki & 2,66 & 2,58 & 2,68 \\
\hline & & krytykuje & 2,13 & 1,84 & 2,24 \\
\hline & & odmawia pomocy & 1,34 & 1,4 & 1,66 \\
\hline & & stroi sobie żarty & 1,61 & 1,35 & 1,5 \\
\hline
\end{tabular}

Należy zaznaczyć, iż powyższe średnie mogły wahać się w przedziale od 1 do 5 , przy czym wartość najwyższa oznaczała zdecydowaną obecność danego znaku rozpoznania.

Źródło: opracowanie własne.

Oprócz opisanych już aspektów, warto dostrzec także inne, które zostały zaznaczone w tabeli 1. Widać tutaj, iż podopieczni tutorów znacznie lepiej oceniają swoich opiekunów w kontekście pozyskiwanych od nich znaków rozpoznania, niż dzieje się to w przypadku uczniów ze szkół, w których obowiązuje tradycyjny model wychowawstwa klasowego. Szczególnie duża różnica dotyczy kategorii „dzielenia się z uczniem uwagami”, ale także chwalenia ucznia przez nauczyciela. W większym stopniu młodzież ta czuje się też wysłuchana przez swoich tutorów. Dane te pokazują zatem, że zdaniem uczniów tutorzy częściej niż wychowawcy dają im pozytywne znaki rozpoznania. Sytuacja ta zupełnie inaczej odnosi się do otrzymywanych przez badanych kolczatek. Tutaj ich nadawcami w większym stopniu są wychowawcy, którzy w opinii badanych częściej lekceważą, krytykują i odmawiają pomocy swoim podopiecznym. Co warte dostrzeżenia, w tym obszarze najlepiej wypadają tutorzy ze szkół wdrażających tę metodę, gdyż w niektórych aspektach licealiści „ALA” swoją opinią o tutorach zbliżają się do opinii uczniów o ich wychowawcach. Te dotyczą szczególnie kwestii krytyki. Możliwe, że na taki stan rzeczy ma wpływ z jednej 
strony duża otwartość „alowych” tutorów, którzy być może mają poczucie, iż mogą udzielić swoim podopiecznym szczerej (krytycznej) informacji zwrotnej. Istnieje też prawdopodobieństwo, że ta różnica wynika z tego, iż tutorzy ze szkół wdrażających, ucząc się bycia tutorem, okazują szczególną ostrożność $\mathrm{w}$ relacjach z uczniem.

Powyższy opis uzyskanych w procedurze badawczej wyników pozwala w znaczący sposób potwierdzić wstępne założenia. Badani uczniowie wskazali na obecność strouków otrzymywanych przez nauczycieli, przy czym jednak ich poziom różnił się w zależności od typu relacji. Pozytywne znaki rozpoznania w większym stopniu można bowiem przypisać tutorom, podczas gdy obecność negatywnych znaków rozpoznania częściej towarzyszyła relacjom wychowawczym. Oczywiście przedstawiane tutaj zagadnienia wymagają dokonania pogłębionych, dalszych analiz, te jednak wykraczają poza ramy niniejszego opracowania. Należy jednak zauważyć, że zaprezentowane powyżej wyniki sugerują, iż badanie poziomu i charakteru znaków rozpoznania obecnych w relacji uczeń-nauczyciel stanowi interesującą badawczo przestrzeń. Warto, aby ta stawała się bardziej obecna w rodzimej literaturze przedmiotu ${ }^{11}$, szczególnie że płynące z niej wnioski, w bezpośredni sposób aplikować można do szkolnej praktyki.

\section{Podsumowanie}

Jeden z tutorów $\mathrm{w}$ otwartym wywiadzie z autorką niniejszych rozważań przyznał: „Tutor jest dobrym nauczycielem, doradcą i człowiekiem godnym zaufania, stara się być dla podopiecznego wzorem osobowym. Wierzy w jego możliwości, wspiera go i doradza, inspiruje i skłania do myślenia, dzieli się własnym doświadczeniami i wiedzą". Zatem zgodnie z założeniami - dostrzega swojego podopiecznego, dając mu znaczną liczbę szczególnie pozytywnych znaków rozpoznania, co też potwierdziły zilustrowane powyżej badania. Należy zauważyć, że dokonana tutaj esencjonalna prezentacja wskazała, iż zdaniem uczniów, w odniesieniu do pracy tutorów, wychowawcy w mniejszym stopniu obdarzają swoich podopiecznych pozytywnymi znakami rozpoznania, a także częściej przekazują im kolczatki. W tym kontekście można uznać, że tutoring pozwala na budowanie bliższych relacji. Metoda ta umożliwia bowiem uczniowi doświadczanie obecności osoby dorosłej (niebędącej rodzicem), która poprzez

11 Jak dotąd tematyka rozpoznawania znaków rozpoznania w przestrzeni szkoły obecna była w największym stopniu w pracach Zespołu Badawczego Edukacyjnej Analizy Transakcyjnej oraz Doroty Pankowskiej. 
systematyczny kontakt może stać się postacią dla niego znacząca, wspierającą jego rozwój w różnych obszarach życia, wykraczających poza te związane choćby z uzyskiwanymi efektami kształcenia. Taka rola tutora z pewnością jest nie do przecenienia.

\section{Bibliografia}

Barrow G. (2007), Transactional Analysis, Pastoral Care and Education, „Pastoral Care in Education", nr 25:1, DOI: http://dx.doi.org/10.1111/j.1468-0122.2007.00396.x

Baum-Baicker C., de Torres C. (1982), Sensory Based Target Strokes, „Transactional Analysis Journal", nr 12 (3).

Berne E. (2007), Dzień dobry... i co dalej?, Dom Wydawniczy Rebis, Poznań.

Berne E. (2004), W co graja ludzie. Psychologia stosunków międzyludzkich, WN PWN, Warszawa.

Berne E. (1978), Principles of group treatment, Grove Press, New York.

Budzyński M. (2009), Tutoring szkolny - jak przez dialog rozwijać ucznia i motywować go do nauki, [w:] P. Czekierda, M. Budzyński, J. Traczyński, Z. Zalewski, A. Zembrzuska (red.), Tutoring $w$ szkole między teoria a praktyka zmiany edukacyjnej, Towarzystwo Edukacji Otwartej, Wrocław.

Czapiński J. (1978), Dyferencjał semantyczny, [w:] L. Wołoszynowa (red.), Materiały do nauczania psychologii, seria III, t. 3, WN PWN, Warszawa.

Czubkowska S. (2013), Badanie PISA: Sukces polskiej edukacji? Eksperci maja watpliwości, http://serwisy.gazetaprawna.pl/edukacja/artykuly/763283, pisa-sukces-polskiejedukacji-eksperci-maja-watpliwosci.html (16.01.2014).

Dieser R. B. (1997), Empirical Research on Attribution Theory: Research Thoughts on Stroking, „Transactional Analysis Journal”, nr 27 (3).

Fijałkowski A. (2009), Z dziejów myślenia o tutoringu - krótki zarys historii indywidualnego kształcenia wychowania, „Kwartalnik Pedagogiczny”, nr 2 (212).

Jagieła J. (2012), Stownik analizy transakcyjnej, Wydawnictwo Akademii im. J. Długosza, Częstochowa.

Gregory J. (2000), Human Science Research: A Mater of Quality, „Transactional Analysis Journal", nr 30 (2).

Hejwosz D. (2010), Edukacja uniwersytecka i kreowanie elit społecznych, Oficyna Wydawnicza „Impuls”, Kraków. 
Http://www.tutoring.pl/ (04.12.2013).

Linde-Usiekniewicz J. (2005), Stownik angielsko-polski, WN PWN-Oxford, Warszawa.

McKenna J. (1974), Stroking profile: Application to Script Analysis, „Transactional Analysis Journal", $\mathrm{nr} 4$ (4).

Okoń W. (1981), Słownik pedagogiczny, WN PWN, Warszawa.

Oller-Vallejo J. (1994), Using Attributive Strokes to Differentiate Natural Traits, „Transactional Analysis Journal", nr 24 (3).

Pankowska D. (2012), Analiza transakcyjna w edukacji czy edukacyjna analiza transakcyjna? - próba porzqdkowania znaczén, „Edukacyjna Analiza Transakcyjna”, nr 1.

Pankowska D. (2010), Nauczyciel w perspektywie analizy transakcyjnej, Wydawnictwo Uniwersytetu Marii Curie-Skłodowskiej, Lublin.

PISA 2012 Results in Focus. What 15-year-olds know and what they can do with what they know, The Organization for Economic Co-operation and Development, http://www. oecd.org/pisa/keyfindings/pisa-2012-results-overview.pdf (03.12.2013).

PISA under attack, Montrose42's Blog. Commentaries on education policy, http://montrose42.wordpress.com/2011/04/30/pisa-under-attack/ (16.01.2014).

Półturzycki J. (1999), Edukacja dorosłych za granica, Wydawnictwo Adam Marszałek, Toruń.

Quintero L. de, Boersner D. (1982), Specific Strokes for Specific Needs, „,Transactional Analysis Journal", $\mathrm{nr} 12$ (4).

Rogoll R. (2010), Aby być sobq. Wprowadzenie do analizy transakcyjnej, WN PWN, Warszawa.

Rubacha K. (2008), Metodologia badań nad edukacja, Wydawnictwa Akademickie i Profesjonalne, Warszawa.

Sarnat-Ciastko A. (2011), Tutoring $w$ perspektywie analizy transakcyjnej, [w:] J. Jagieła (red.), Analiza transakcyjna w edukacji, Wydawnictwo Akademii im. J. Długosza, Częstochowa.

Sprawozdanie Prezydenta Miasta Wrocławia z realizacji zadań w 2012 r. (2013), Urząd Miasta Wrocławia, Wrocław.

Suchecka J. (2013), Polscy uczniowie w światowej czołówce! Sa wyniki badania PISA. Wyprzedziliśmy m.in. Niemcy, Anglię, http://wyborcza.pl/1,75478,15064902, Polscy_uczniowie_w_swiatowej_czolowce_Sa_wyniki_badania.html\#ixzz2rys1B46R (03.12.2013). 
Adrianna Sarnat-Ciastko Czy mnie dostrzegasz, czy odpowiadasz na moje potrzeby?

Tapper T., Palfreyman D. (2000), Oxford and the decline of collegiate tradition, Woburn Press, London.

Topping K. (1994), A Typology of Peer Tutoring, „Mentoring \& Tutoring: Partnership in Learning”, nr 2:1, DOI: http://dx.doi.org/10.1080/0968465940020104

Wagner L. (1982), Peer teaching historical perspective, Westport-London: Greenwood Press. 
